\title{
What is 'post-race' and what does it reveal about contemporary racisms?
}

DOI:

10.1080/01419870.2016.1202430

\section{Document Version}

Accepted author manuscript

Link to publication record in Manchester Research Explorer

\section{Citation for published version (APA):}

Valluvan, S. (2016). What is 'post-race' and what does it reveal about contemporary racisms? Ethnic and racial studies, 39(13), 2241-2251. https://doi.org/10.1080/01419870.2016.1202430

\section{Published in:}

Ethnic and racial studies

\section{Citing this paper}

Please note that where the full-text provided on Manchester Research Explorer is the Author Accepted Manuscript or Proof version this may differ from the final Published version. If citing, it is advised that you check and use the publisher's definitive version.

\section{General rights}

Copyright and moral rights for the publications made accessible in the Research Explorer are retained by the authors and/or other copyright owners and it is a condition of accessing publications that users recognise and abide by the legal requirements associated with these rights.

\section{Takedown policy}

If you believe that this document breaches copyright please refer to the University of Manchester's Takedown Procedures [http://man.ac.uk/04Y6Bo] or contact uml.scholarlycommunications@manchester.ac.uk providing relevant details, so we can investigate your claim.

\section{OPEN ACCESS}




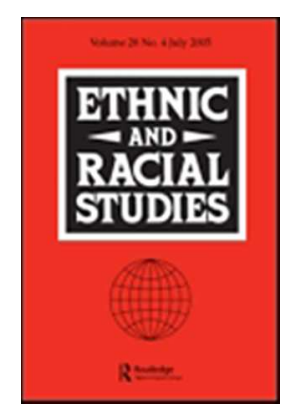

\section{DAVID GOLDBERG BOOK SYMPOSIUM- ARE WE ALL POSTRACIAL YET?}

\begin{tabular}{|r|l|}
\hline Journal: & Ethnic and Racial Studies \\
\hline Manuscript ID & Draft \\
\hline Manuscript Type: & ERS REVIEW - BOOK SYMPOSIUM \\
\hline Keywords: & $\begin{array}{l}\text { post-race, neoliberalism, animalization, global relationalities, Cultural } \\
\text { Racism, Manhunts (Chamayou) }\end{array}$ \\
\hline \multicolumn{2}{|l}{} \\
\hline
\end{tabular}

SCHOLARONE ${ }^{m}$

Manuscripts

URL: http://mc.manuscriptcentral.com/rers ethnic@surrey.ac.uk 


\footnotetext{
${ }^{1}$ This is not to discount the formidable contributions and debates charted by figures such as Barnor Hesse, Brett St Louis, Alana Lentin and Eduardo Bonilla-Silva.

${ }^{2}$ Alternatively, racism is parcelled away as being solely the preserve of avowedly extremist, Far-Right groups (e.g. the English Defence League, British National Party, and Britain First regarding the UK context). Racism thereupon obtains such a narrow remit that to fall foul of it requires the unashamed bombast of the above groups. I thank James Rhodes for drawing attention to this detail.

${ }^{3}$ One of the more galling moments in Britain's recent political pageantry was David Cameron's sombre lauding of the late Nelson Mandela's monumental political legacy. If would take an informed mind to remember that Cameron's younger political affiliations strongly wedded him to the rabidly anti-ANC, pro-Apartheid cheerleading of the Conservative Party, and its youth wings in particular. The notorious 'Hang Nelson Mandela' badges, posters and songs (New Statesman, 2013) allegedly sported by the younger ideologues of Thatcherism (Federation of Conservative Students) speaks for itself, even if Cameron himself did not have any direct involvement in these activities.
} 
alive' $[76,161])$ transcendence: a transcendence where race no longer matters and where only individual will and character either enables or hampers a person's life-chances. ${ }^{4}$

Consequently, what materialises is a state of affairs where discursively time is called on racism, whilst structurally it continues unabated - i.e. 'racisms without racism' (159). Goldberg's seminal writing on this terrain stakes out in turn a deceptively simple but forceful claim: the post-racial is not merely a significant feature of contemporary racisms, but it is its very constitutive base. Put differently, all racisms of the present must be assessed by how they are instantiated in a time when it is claimed to be over. The popular curtain call on race and racism is seen by Goldberg as producing unique racial 'conditions' (26), 'logics' (60) and 'subjects' (106). ${ }^{5}$ Attention turns therefore to how the same discursive frameworks continue to produce and circulate race-meaning whilst rendering overt references to race verboten ${ }^{6}-$ 'Postracial racism speaks to processes where a racial subtext is pressed without an accompanying racial text' (Valluvan et al. 2013: 171).

Some observers of racism will be wary of this attempt to ask post-race to do so much explanatory work. Making post-race generate such diffuse ontological purchase (i.e. 'conditions', 'logics', 'subjects', and futures) is indeed a heavy explanatory load to bear. Accordingly, a certain suspicion of post-race as constituting a unique analytic frame has begun to surface in some circles, evident for instance in Meer's (2016: 395) recent claim that the 'post-race thesis [remains] analytically unappealing and empirically unpersuasive', unable to capture the 'messiness' of contemporary racemaking and anxiety. Whilst Meer does not expand on this claim, there are certainly some aspects of this expansive analytic turn to the post-racial that I think warrant constructive interrogation.

\section{Liberalism for neoliberal times}

First, it might be posited that the post-racial is in fact symptomatic of the liberal conceit writ large. Whilst this recognition (which is in fact central to Goldberg's 2009 The Threat of Race) does not dilute the importance of the post-racial illusion in configuring contemporary racial structures, it does situate post-race within wider and contiguous ideological drifts. In short, all neoliberalism is about writing out attentiveness to structural constraints. Recall for instance the emphatic post-Cold War pronouncements that we live in post-class times - an intuition central to the current wave of austerity regimes. It would after all be uncontroversial to observe that contemporary political culture is rife with pundits who routinely summarise the present as one without class, only consumers - or, even more perversely, class is presented as a self-afflicted condition. Or consider how deliberations about gender equality rest on a particular narration of the present where patriarchy's hold is seen primarily to be a historical sin of the past or the preserve of particular ethnic groups. Furthermore, an analogous cultural eulogising of past feminist, trade union, antiracist and Gay Rights struggles respectively is marshalled in order to overdetermine the present as one of teleological triumph - see the recent spate of UK box-office sensations that look backwards for progressive political content (e.g. Pride, Suffragette, Selma, 12 Years a Slave, The Spirit of '45, Made In Dagenham, Indian Summers ${ }^{7}$ ). Of course, activists and progressives of various traditions have always asserted that such structural impediments continue to matter, but the prevailing common-sense is indeed to picture the contemporary as one where social mobility is primarily an epiphenomenon of individual effort, whilst the state, as Goldberg rightly observes, is merely meant

\footnotetext{
${ }^{4}$ Goldberg (138), via a wittily literal reading of the Anthropocene, calls this particular neoliberal imaging of humanity - the era of 'new man' (private, solipsist, and uncompromisingly resilient).

${ }^{5}$ These iconic subjects that the post-racial works through are according to Goldberg's schema: Blackness, the Muslim-Gazan, and the Migrant, (125-151).

${ }^{6}$ See also a recent research piece by Harries (2014) about how post-racial deceptions prevent victims of racism from articulating their experiences.

${ }^{7}$ This is not a criticism of the film-makers themselves, but rather, draws attention to how certain kinds of films can garner such box-office acclaim whilst the important themes it entertains are jettisoned from broader political discussions of present social conditions.
} 
to facilitate and/or securitize the endeavours of private, rational-choice actors. It certainly remains a valid truism that each of these different structural formations are autonomous, exercising their own vagaries and exclusions; but the broader ideological continuities in terms of legitimating and rewashing these multiple inequalities does I think require firmer acknowledgment when situating the specific purchase of post-race.

\section{Cultural and New racism?}

Second, it is certainly the case that race, originally deployed as a primordial and immediately visible category, can no longer be named, only continually insinuated - e.g. racial meanings and stereotype continue to be propagated concomitant to a blanket ideological denial that race is even consequential to the making of life. Goldberg, akin to an influential argument put forth by Makdisi regarding the spatial and architectural workings of Israeli supremacy, identifies this status quo as 'the erasure of the erasure' (75). The primary erasure of rights and capabilities as actualised by racism and the subsequent erasure of any reference to the processes that have rendered these inequalities and exclusions - i.e. 'racisms without racism' (159) or making invisible the making of people invisible (Makdisi, 2010: $535^{8}$ ).

But it should also be noted that other contiguous taxonomies, always folded into the historical play of racial formations, are indeed regularly named, evoked and asserted - not least ethnicity, religion and citizenship: e.g. Chinese couples make for authoritarian but effective parents ('Tiger Moms'); Muslims are self-segregating, insular and of suspicious loyalties; African-Americans are prone to criminality, dependency and nihilistic materialism; or migrants are work-shy and/or work excessively (depending on what brand of hysteria one subscribes to). These intersecting appeals to the ethnoracial, ethno-religious, and ethno-legal constitute the active nomenclature which articulate contemporary racial and nationalist formations - but if so, the social is not characterised by a question of race no longer being named, but rather, how is it in fact named. Again, this reading is certainly consonant with the wider argumentation of Goldberg - whose fundamental claim is that race continues to circulate but it is racism that is denied. But if so, it would be instructive to corral here the wider body of racism research that has sought to reveal the remade terms by which race does indeed get named but becomes cloaked in the decorum of post-racial propriety - i.e. no more talk of biology, genetics, and intrinsic inferiority.

A theory of racism is of course a theory of modernity. Theories of racism have accordingly always had to reckon with modernity's complexity in circulating racial frameworks - not least via the cementing of the ethno-national's everyday allure and the remaking of religious hierarchy vis-à-vis secular liberal individualism. It is therefore particularly helpful I think to draw upon certain already well-established concepts when charting the precise mechanisms by which the post-racial operates concepts such as anti-Muslim racism/Islamophobia, 'new' and 'cultural' racism, and even Orientalism. Some might of course consider extant conceptualisations of cultural and new racism to be somewhat artificial - in terms of actualising all too clean a break with previous forms of allegedly biological and scientific racism. This charge of false periodization is something I would second - not only in that it understates the role of 'cultural attributes' in generating previous racial exclusions, but in all too hastily writing out the biological, genetic and formally legal (e.g. see citizenship and residency regimes[Byrne, 2014]) from accounts of the contemporary. But in spite of these challenges, I do find these concepts when properly purposed helpful for working through the full and

\footnotetext{
${ }^{8}$ The full quote in its original context regarding the Israeli security wall is: 'From the Israeli point of view, the effect is not only to render the Palestinians on the other side invisible but, even if only in fits and starts, to render the process of rendering them invisible itself invisible. When possible, then, the wall as the signifier of erasure is itself erased in turn-as though there were some magic trick that could erase the Palestinians from the landscape without the trace of that erasure being evident' (Makdisi, 2010: 535).
} 
expansive thrust of the post-racial thesis. I am particularly drawn here to Alexander's (2016) recent reply to Patterson's (2015) The Cultural Matrix for an instructive précis of how central culture framed as a discrete property of different ethno-racial groups - has become to both the operationalization as well as rationalization of racism and racial outcomes. Consequently, given the complex profile of 'culturalism' in steering contemporary racisms, it would be instructive I think for the broader post-race literature to give this terrain a wider and/or more direct incorporation.

\section{Animalization}

There is however something to the contemporary realisation of racial exclusion that goes beyond the representation of ethno-racial groups along discrete, pathological and incompatible cultural sets. Namely, there is still a particular kind of race-making that is always about a broader ontology of human and non-human (or less-than-human) which renders racism's capacity for violence, indifference and visceral psychoanalytic charge so distinctive. Goldberg's recurring discussion of 'animalization' (48-59, 85-88, 110-112) when situating the post-racial is therefore particularly welcome when trying to think beyond the current focus on the 'cultural' and 'new'. And whilst the terminology of 'affect' (Ahmed, 2004; Hughey, 2015; Jones and Jackson, 2014) that has become so prominent in certain social science circles might have given a particular analytic breadth for thinking about the 'infrahuman' (Gilroy, 2000; 2010), it remains instructive of Goldberg to remind students of racism that race-making is as much about humiliation and making the racial Other unbearable (repulsive, dirty, threatening, mutinous, grim, lecherous, swarming, proliferating, etc.) as it is about more direct rationalizing appeals to cognitive sense-making systems ('they take jobs', 'are a fiscal and/or security threat', are 'prone to criminality', are 'misogynistic'). Goldberg's passing account (132-145) of how news cycles framed the recent Ebola crisis and bombing of Gaza respectively does substantiate particularly well this analytic emphasis on 'animalization' and 'anthroporaciality' (138139), a move which is also compellingly present in Pitcher's (2014: 98-128) recent Consuming Race.

There is also an interesting and I believe underexplored analogue to be had here with Chamayou's (2012) beguiling, if synoptic, tour de force, Manhunts. Chamayou's core contention is that Power in its diffuse and various historicised forms (e.g. colonial and nation-state racism, bourgeois merchant supremacy, feudal aristocratic privilege, Vatican-cum-monarchic rule, Antiquity patricianism) always draws upon a particular making of who is to be hounded, rounded up, kept at bay, and so forth along a broad continuum of coercion and exclusion. Put simply, power is always, in part, about who is to be the object of force, who shall do the enforcing, and how is it to be enforced - a force which results in particular technologies of classification, hunting, surveillance, internment, killing and fortification. When transposed to the particular exigencies of contemporary racism, a variety of subjects - be it the young black man in the metropolis, the refugee braving the unforgiving seas, or the Muslim roaming war-torn lands or his/her suburban mosque - all become objects of a unique, historically contingent state force. And this application does certainly rally particular affectively loaded representational coordinates (i.e. animalization) that makes this force both viable and necessary.

\section{Synchronic racisms}

In light of these digressions via the play of animalization, force, 'culture' and the neoliberal form more broadly, it is necessary to re-centre here the specificities of post-racial racism. Goldberg argues that the rewashed terms of racisms' exclusionary remit relies fundamentally on the illusion that racism has passed. This makes for an extraordinarily efficient racial structure. Namely, there is nothing to name - indeed, any charge of racism is promptly negated by the claim that it is antiracists themselves who fetishize race, a fetishism for the discredited logic of the past that any selfrespecting progressive is implored to renounce. Anti-racists are thus reduced to the fate of wailing 
Cassandras. Consider for instance Goodhart (2014), a figurehead of British anti anti-racist polemics, and his 'less is more' thesis. ${ }^{9}$ For Goodhart, the more that racism wanes (which is of course taken as a given), the more that anti-racists and misguided latte-drinking liberals evoke the spectre of racism (i.e. the proverbial 'race-card'). The idiocy lies hereby not with racism, but with anti-racism.

In this context, racist discourses always masquerade as being claims of a different order - defensive postures about security, about the welfare state, about a beleaguered 'white working-class', ${ }^{10}$ about the commitment to sexual and gender equality, about international stability, about the EU and its largesse, about scare resources, or about history and the putative unity and public morality of prewar colonial Britain. And any concerted effort to break the deafening silence about racism in the midst of all this chicanery is what becomes identified as the primary instantiation of racism. Herein, if the broader structures that produce multiple exclusions, oppressions and/or exploitations cannot itself be named ('erasure of the erasure'), it is the ultimate realisation of a hegemonic racial common-sense - an inequality without descriptors, without sense, without presence. It is one thing to have a world that is unequal, it is quite another if that inequality cannot even be noted.

On this score, there is an interesting secondary analytic emphasis that shadows much of Goldberg's argument. It is intimated here that the post-racial structures steering contemporary racisms become best discernible only if seen through a relational sociology (as opposed to a historically comparative method) that takes the world at large as its rightful analytic and political canvas (123-124, 152-53; Goldberg, 2015; Bhambra, 2007). The post-racial deceptions of the present are best revealed not by bringing it into analytic relation to what previously informed a particular location, but rather, in relation to the political processes and exclusions unfolding synchronically at other locations. Though I suspect that Goldberg's immediate analytic emphasis is slightly different, I purpose this argument as suggesting that the racial meanings as generated globally are continuously absorbed into the political and social vicissitudes of a local space; but in so doing, race need not be actively named given that the circuitous force of its signification already operates through established, globally resonant tropes. Put differently, certain iconic racial meanings are always-already cued through broader, and increasingly digital, global mediations - e.g. the rabid Muslim; the black criminal; the lecherous or scheming, undeserving migrant.

Goldberg's call for a globally construed relational analysis chimes particularly sharply in light of certain problematic tendencies common to contemporary academic output (Valluvan and Kapoor, 2016: 379). Partly owing to the national technologies of academic formation and the policy-led drawing of empirical boundaries, ${ }^{11}$ excessive analytic credence is I believe given to a particular national or metropolitan history. This preference for locally rooted historical contingencies (which in itself is not a problem) does unfortunately come at the analytic expense of those factors and developments occurring synchronically across multiple cotemporaneous global nodes. Put glibly, regardless of where one is writing from and about, Western Asia always matters; Israel/Palestine always matters; the dissemination of an American consumer culture and its particular configuration of racial titillation and status always matters; the rise of East Asian economic clout always matters. It is these global circulations which are all co-constitutive of the racisms that are operationalized within a particular local and/or national context.

\footnotetext{
${ }^{9}$ See also the Prospect (2010) Issue, 'Rethinking Race: Has Multiculturalism had its Day', published during Goodhart's influential tenure as founding Editor of the putatively left-of centre periodical. This publication is widely considered a landmark moment in British political culture's confident assent to a post-racial era and all its characteristic motifs.

${ }^{10}$ See here the enchantment of British nationalist punditry with an unusual entity that is said to be the 'white working-class'.

${ }^{11}$ See discussions on 'methodological nationalism' as parsed by Beck and Beck-Gernsheim (2009) and Wimmer and Glick Schiller (2002).
} 
With my own research priorities in mind, this observation becomes particularly important regarding the proper place of the UK vis-à-vis European mediations of anti-multiculture, new nationalist anxieties. What I consider to be British academia's tendency towards an Anglophone provincialism has obfuscated awareness of how the primary constitutive forces in the making of 'new racial subjects' (Redclift, 2014) and national crises within the 'post-racial UK' (Kapoor, 2013) are in fact processes common to the entirety of Western Europe. I am also thinking of how racial hysterias are circulated transnationally - see how the rapidly thickening anti-Muslim sentiment in the UK rests on a regional and/or international parade of events (each renewing the previous): Paris after Paris, Copenhagen after Toulouse, Cologne after Birmingham. Or how the European demonization of the migrant can constantly assume different points of emphasis as necessary (the Eastern European, the Roma, the Muslim Arab, and the black African). Or how a war-making neoconservative climate across Europe continuously absorbs Israeli reference points, the latter 'recharging' particularly complex, 'deadly' and intricately knotted anti-Semitic tendencies within Europe (141-142).

\section{Conclusion}

It is clear that attentiveness to the post-racial as charted by Goldberg facilitates an original and intricate insight into what constitutes the racisms of today. Goldberg's working of this concept allows for considerable clarification regarding the place of contemporary racisms vis-à-vis animalization, global relationalities and, more broadly, the neoliberal visualisation of humanity. I also hope that this discussion has made apparent that the analytic value of post-race is perhaps best understood in terms of how it both incorporates as well as exceeds the explanatory terrain already serviced by the concept of 'Cultural Racism'.

In concluding, I also wish to suggest that the considerable ideological deceptions of the post-racial must not be allowed to obscure the alternative resonance often attributed to the term - namely, post-race as the hope that we might one day work beyond the violent, exploitative and divisive modernist ontology of race (St Louis, 2015). The final pages of Are We All Postracial Yet does elegantly engage this alternative tradition that has, after all, been so central to much anti-racist history and scholarship. Goldberg articulates here a daring and ultimately affirmative fashioning of an anti-racist, 'non-racial' humanism - a vision of humanism that does not slip into the neo-imperial and anti-difference tropes humanism is otherwise prone to (180-181). Whether others will agree with Goldberg's preference for the 'non-racial' as a more workable and sincere political horizon - as opposed to the post-racial's deceptive and normative baggage - is a matter for future debate. But it remains vital of Goldberg to issue this important reminder regarding the need for political horizons that are less saddled by the appeal of 'ethno-national' community. Put differently, any visualization of a future that is to be characterised by 'freedom' (180) must be able to more purposefully harness the already considerable anti-communitarian, cosmopolitan dispositions being routinely cultivated by various activists and denizens the world over (Gilroy, 2004; Valluvan, 2016).

\section{References}

Ahmed, S. 2004, The Cultural Politics of Emotion, New York, NY: Routledge

Alexander, C. 2016, 'The Culture Question: A View from the UK', Ethnic and Racial Studies, xx: x, xx$\mathrm{xx}$

Beck, U. and Beck-Gernsheim, E. 2009, 'Global Generations and the Trap of Methodological Nationalism for a Cosmopolitan Turn in the Sociology of Youth and Generation', European Sociological Review, 25:1, 25-36 
Bhambra, G. 2007, 'Sociology and Postcolonialism: Another 'Missing' Revolution?', Sociology, 41:5, 871-884

Byrne, B. 2014, Making Citizens: Public Rituals and Personal Journeys to Citizenship, Basingstoke, HA: Palgrave Macmillan

Chamayou, G. 2012, Manhunts: A Philosophical History, Princeton, NJ: Princeton University Press

Gilroy, P. 2010, Darker than Blue: On the Moral Economies of Black Atlantic Culture, Cambridge, MA: Harvard University Press

Gilroy, P. 2000, Between Camps: Nations, Culture and the Allure of Race, Abingdon, OX: Routledge

Goldberg, D.T. 2015, 'Racial Comparisons, Relational Racisms: Some Thoughts on Method' in Murji, K. and Solomos, J. (eds), Theories of Race and Ethnicity: Contemporary Debates and Perspectives, Cambridge, CB: Cambridge University Press, 251-261

Goldberg, D.T. 2014, Sites of Race: Conversations with Susan Searls Giroux, Cambridge, CB: Polity Press

Goldberg, D.T. 2013, 'The Postracial Contemporary' in Kapoor, N., Kalra, V. and Rhodes, J. (eds), The State of Race, Basingstoke: Palgrave Macmillan, 15-30

Goldberg. D.T. 2009, The Threat of Race: Reflections on Racial Neoliberalism, Oxford, OX: WileyBlackwell

Goodhart, D. 2014, 'Racism: Less is More', The Political Quarterly, 85:3, 251-258

Harries, B. 2014, 'We Need to Talk about Race', Sociology, 48:6, 1107-1122

Hughey, M. 2015, 'The Sociology of Whiteness: Beyond Good and Evil White People', Murji, K. and Solomos, J. (eds), Theories of Race and Ethnicity: Contemporary Debates and Perspectives, Cambridge, CB: Cambridge University Press, 214-232

Jones, H. and Jackson, E. (eds) 2014, Stories of Cosmopolitan Belonging: Emotion and Location, Abingdon, OX: Routledge

Kapoor, N. 2013, 'The Advancement of Racial Neoliberalism in Britain', Ethnic and Racial Studies, $36: 6,1028-1046$

Makdisi, S. 2010, 'The Architecture of Erasure', Critical Inquiry, 36: Spring, 519-559

Meer, N. 2016, 'Sociologists, Archbishops, and 'making a verb of a noun", Ethnic and Racial Studies, 39:3, 392-396

New Statesman [Online] 2013, 'Twitter Fact-Check: David Cameron didn't want to “Hang Nelson Mandela" in the 80s', December 6, http://www.newstatesman.com/media-mole/2013/12/twitterfact-check-david-cameron-didnt-want-hang-nelson-mandela-80s

Patterson, O. and Fosse, E. (eds) 2015, The Cultural Matrix: Understanding Black Youth, Cambridge, MA: Harvard University Press

Pitcher, B. 2014, Consuming Race, Abingdon, OX: Routledge

Prospect, 2010, 'Rethinking Race', 175: October

Redclift, V. 2014, 'New Racisms, New Racial Subjects? The Neo-liberal Moment and the Racial Landscape of Contemporary Britain', Ethnic and Racial Studies, 37:4, 577-588 
St Louis, B. 2015, 'Can Race Be Eradicated: The Post-racial Problematic' in Murji, K. and Solomos, J. (eds), Theories of Race and Ethnicity: Contemporary Debates and Perspectives, Cambridge, CB:

Cambridge University Press, 114-138

Valluvan, S. 2016, 'Conviviality and Multiculture: A Post-integration Sociology of Multi-ethnic Life', YOUNG, 24:3

Valluvan, S. and Kapoor, N. 2016, 'Notes on Theorizing Racism and Other Things', Ethnic and Racial Studies, 39:3, 375-383

Valluvan, S., Kapoor, N. and Kalra, V. 2013, 'Critical Consumers Run Riot in Manchester', Journal of Cultural Research, 17:2, 164-82

Wimmer, A. and Glick Schiller, N. 2002, 'Methodological Nationalism and Beyond: Nation-state Building, Migration and the Social Sciences', Global Networks, 2:4, 301-334

URL: http://mc.manuscriptcentral.com/rers ethnic@surrey.ac.uk 